\title{
Assessment of Sahiyya (Accredited Social Health Activist) in relation to antenatal services: Ormanjhi, Ranchi, Jharkhand
}

\author{
Shilpa Karir, Shamim Haider, Vivek Kashyap, Vidya Sagar*, Shashi Bhushan Singh
}

\begin{abstract}
Department of Preventive and Social Medicine (PSM), Rajendra Institute of Medical Sciences (RIMS), Ranchi-
\end{abstract} 834009, Jharkhand, India

Received: 11 February 2015

Accepted: 21 March 2015

*Correspondence:

Dr. Vidya Sagar,

E-mail: drsagarvidya@gmail.com

Copyright: ( $)$ the author(s), publisher and licensee Medip Academy. This is an open-access article distributed under the terms of the Creative Commons Attribution Non-Commercial License, which permits unrestricted non-commercial use, distribution, and reproduction in any medium, provided the original work is properly cited.

\begin{abstract}
Background: Accredited Social Health Activist (ASHA) acts as a 'bridge' between the rural people and health service outlets and would play a central role, in achieving national health and population policy goals. In Jharkhand ASHA is known as "Sahiyya". The present study was aimed to assess Sahiyyas in relation to antenatal services delivered by her in the field practice area Ormanjhi of Rajendra Institute of Medical Sciences (RIMS), Ranchi.

Methods: This was a community based cross sectional study. All Sahiyyas (26), women having children under 3 years of age (196), pregnant women (140), Anganwadi workers (AWWs) (16) and Auxiliary Nurse Midwives (ANMs) (6) from the study area were recruited for the study. Assessment of antenatal services delivered by Sahiyyas was done based on interview with Sahiyyas which was then crosschecked through the responses of beneficiaries, AWWs and ANM.

Results: All Sahiyyas in the study area were aware about her job responsibilities like help during registration and mobilization during pregnancy but when cross checked, $70.2 \%$ and $60.9 \%$ beneficiaries received help during registration and mobilization. Out of 336 beneficiaries, only $23.2 \%$ and $19.9 \%$ responded that were counselled by Sahiyyas on nutrition and adequate rest during pregnancy during their home visits.

Conclusions: Sahiyyas were well aware of her responsibilities related to antenatal services like counselling mothers on diet, rest and other health advices through home visits but these jobs were not being done passionately by her as other incentive oriented jobs.
\end{abstract}

Keywords: Sahiyya, Antenatal, AWW

\section{INTRODUCTION}

The National Rural Health Mission (NRHM) has designated Accredited Social Health Activist (ASHA) for all high focus sates including Jharkhand. ${ }^{1}$ This was aimed to provide primary medical care, advice the villagers on sanitation, hygiene, antenatal and postnatal care, escorting expectant mothers to hospital for safe delivery thus encouraging institutional delivery. ASHAs are supposed to act as a 'bridge' between the rural people and health service outlets and would play a central role, in achieving national health and population policy goals. ${ }^{2}$ ASHA must be a woman resident of the village preferably 'Married/widow/divorced/separated' and preferably in the age group of 25 to 45 years. She should be a literate woman with formal education up to eighth class. $^{3}$

Today the country has $8,94,525 \mathrm{ASHAs}^{4}$ in place and in Jharkhand there are $40964^{5}$ trained ASHAs - known as "Sahiyyas" (friend) who are working voluntarily all over the state to improve access and provide elementary health services to the community, the major component being Maternal and Child Health (MCH) services. The concept of female health volunteer assisting the rural people in availing the health services in Jharkhand is not new. Even 
before the launch of NRHM, some of the NGOs successfully in 2004 experimented "Sahiyya" a local word meaning "Friend" or "Saheli" in the state, who worked as a link between health care services and the masses. ${ }^{6}$ In order to provide quality health care services to the 'last person in the last household of the last village' the Government of Jharkhand initiated a community based approach - the Sahiyya Movement after a pilot in 2004 to encourage community participation in delivering quality health care to the needy and empowerment of women. ${ }^{7}$ The selection criteria for Sahiyyas is different from the national norm of one per 1000 population and a minimum educational qualification of 8th class pass. In Jharkhand Sahiyya can be selected one for every Tola (Hamlet; a section of a village where often people of the same caste/religion live) and there are no educational restrictions either.

Jharkhand is a predominantly a rural state with a large tribal population living in highly inaccessible areas. Most of the health indicators of Jharkhand are poor in comparison to many states. Jharkhand has a high Maternal Mortality Ratio (MMR) of 219/lakh live births which is quite high than the national data of 178/lakh live births. ${ }^{9}$ This high maternal mortality remains a matter of concern in Jharkhand. Although infant mortality rate (IMR) has reduced substantially during the last decade, now being 38/1000 live birth in Jharkhand, ${ }^{10}$ but still the challenge is to accelerate the decline in both MMR and IMR by providing Maternal and Child Health services $(\mathrm{MCH})$ services thus ensuring a healthy life to mother and child.

Here the role of Sahiyya is important as she is engaged closely with pregnant women and mothers by creating awareness and mobilizing them to avail the $\mathrm{MCH}$ services. The present study was embarked upon assessing the performance of the Sahiyyas related to antenatal services delivered by her in the field practice area.

\section{METHODS}

\section{Study design}

Community based cross sectional study.

\section{Study period}

Total duration of study: 28 months (July 2012 to October 2014).

\section{Place of study}

The study was conducted in the three health sub centres namely Irba, Chakla, and Anandi in Ormanjhi block of Ranchi district including 16 Anganwadi centres (AWCs) which are the rural field practice area for the department of Preventive and social medicine of RIMS, Ranchi, Jharkhand.

\section{Study subjects}

Pregnant women residing in the area for last one year, women having children under 3 years of age who were permanent residents of the village (permanent residents were taken to avoid immigration effects), all Sahiyyas, Anganwadi workers (AWWs) and Auxiliary Nurse Midwives (ANMs) in the field practice area.

Only those who were willing to participate in the study and have given informed consent were interacted.

The work performances of Sahiyyas were assessed based on responses of Sahiyyas regarding her job responsibilities related to antenatal services which were crosschecked through the responses of beneficiaries, AWWs and ANMs.

\section{Total sample size}

The total study subjects interviewed for the study were 336 beneficiaries (Pregnant women $=140$, Women having children under 3 years of age $=196$ ), 16 AWWs working in AWCs, 6 ANMs and all 26 Sahiyyas working under three sub centres.

All pregnant women (140) enrolled in the registers of AWCs for supplementary nutrition and women having children under three years of age (196) enrolled were included in the study to achieve a sample size of 336. The 196 mothers represented about $50 \%$ of the enrolled mothers at AWCs.

\section{Data collection method}

Data from 336 beneficiaries (Pregnant women $=140$, Women having children under 3 years of age $=196), 26$ Sahiyyas, 6 ANMs and 16 AWWs were collected through pre-tested semi-structured questionnaires. A set of five questionnaires were developed to collect data from each set of study subjects. The questionnaire for Sahiyyas was framed based upon the Training module/reading material for ASHA, under NRHM. After listing the 336 beneficiaries, home visits were conducted with the help of Anganwadi Sahayika (Helper of AWW). The beneficiaries were interviewed at their homes about services of Sahiyya in the absence of Sahiyya to prevent bias of results.

AWWs and ANMs were interviewed at the health centre and Sahiyyas were interviewed at their homes. Finally the work performance of Sahiyyas was assessed based on responses of Sahiyyas regarding her job responsibilities related to antenatal services which was crosschecked through responses of beneficiaries, AWWs and ANMs.

\section{Data entry and analysis}

Data obtained from interview of study subjects using five set of questionnaires were entered in MS excel 
spreadsheet after generation of proper template and data analysis was done using SPSS software. Frequency tables and cross tabulations were generated to see the distribution of variable.

\section{RESULTS}

The study of socio-demographic profile of Sahiyyas in terms of age, education, marital status, caste and economic status is important as it might have a bearing on their functional efficacy. Out of total 26 Sahiyyas nearly half of Sahiyyas $11(42.3 \%)$ belonged to age group $32-37$ years followed by $8(30.8 \%)$ between $26-31$ years of age and only $5(19.2 \%)$ from $38-43$ years of age. The minimum age group of Sahiyya was 22 years and maximum was 42 years. Most of them 21 (80.8\%) had formal education of $8^{\text {th }}$ standard and above and one was illiterate. As far as religion is concerned, nearly half of them $11(42.3 \%)$ were Hindu, 9 (34.6\%) were Muslim and $6(23.1 \%)$ belonged to Sarana religion. In the present study out of 26 Sahiyyas, $17(65.4 \%)$ belonged to socioeconomic status (SES) class IV (Upper lower class) and 9 $(34.6 \%)$ to SES class V (lower class) (Table 1).

Table 1: Sociodemographic profile of Sahiyyas $(n=26)$.

\begin{tabular}{|c|c|c|}
\hline $\begin{array}{l}\text { Socio-demographic } \\
\text { variables }\end{array}$ & Number & $\begin{array}{l}\text { Percentage } \\
(\%)\end{array}$ \\
\hline \multicolumn{3}{|l|}{ Age group } \\
\hline $20-25$ & 2 & 7.7 \\
\hline $26-31$ & 8 & 30.8 \\
\hline $32-37$ & 11 & 42.3 \\
\hline $38-43$ & 5 & 19.2 \\
\hline Total & 26 & 100 \\
\hline \multicolumn{3}{|l|}{ Education } \\
\hline Illiterate & 1 & 3.8 \\
\hline Below $8^{\text {th }}$ standard & 4 & 15.4 \\
\hline $8^{\text {th }}$ standard and above & 21 & 80.8 \\
\hline Total & 26 & 100 \\
\hline \multicolumn{3}{|l|}{ Marital status } \\
\hline Married & 25 & 96.2 \\
\hline Widow & 1 & 3.8 \\
\hline Total & 26 & 100 \\
\hline \multicolumn{3}{|l|}{ Religion } \\
\hline Hindu & 11 & 42.3 \\
\hline Muslim & 9 & 34.6 \\
\hline Sarana* & 6 & 23.1 \\
\hline Total & 26 & 100 \\
\hline \multicolumn{3}{|c|}{$\begin{array}{l}\text { Socio economic status (Based on B. G. Prasad } \\
\text { classification (May 2014) }\end{array}$} \\
\hline Class I & 0 & 0 \\
\hline Class II & 0 & 0 \\
\hline Class III & 0 & 0 \\
\hline Class IV & 17 & 65.4 \\
\hline Class V & 9 & 34.6 \\
\hline Total & 26 & 100 \\
\hline
\end{tabular}

*Sarana is a local religion of Jharkhand

\section{Responses of Sahiyya about her knowledge and practices pertaining to antenatal services}

In the present study all the Sahiyyas responded that they help pregnant women in registration of pregnancy and mobilization of women during antenatal checkups. Most of them $22(84.6 \%)$ responded that minimum four antenatal checkups were recommended for all pregnant women and the rest responded less than four visits. Out of six components of antenatal checkups, most of the Sahiyyas responded as regular weight checkup 26 (100\%), IFA tablet intake $25(96.2 \%)$ and two doses of TT injection $23(88.5 \%)$ as ANC components. Awareness about measurement of blood pressure, blood test and urine test as important ANC components was found to be low as compared to other components (Table 2).

Table 2: Knowledge of Sahiyyas regarding her responsibilities related to antenatal checkup and its components $(n=26)$.

\begin{tabular}{|ll|}
\hline & \multicolumn{1}{|c|}{$\begin{array}{c}\text { Number of } \\
\text { Sahiyyas (\%) }\end{array}$} \\
\hline \multicolumn{2}{|c|}{ Antenatal check-up to be advised by Sahiyya to women } \\
\hline $\begin{array}{l}\text { Minimum four Antenatalcare (ANC) } \\
\text { check-ups }\end{array}$ & $22(84.6 \%)$ \\
\hline Less than four ANC checkups & $4(15.4 \%)$ \\
\hline Total & $26(100 \%)$ \\
\hline ANC components* & $26(100 \%)$ \\
\hline 1. $\quad$ Regular weight check-up & $16(61.5 \%)$ \\
\hline 2. $\quad$ Measurement of BP & $19(73.1 \%)$ \\
\hline $3 . \quad$ Blood test for anaemia & $18(69.2 \%)$ \\
\hline $4 . \quad$ Urine test & $25(96.2 \%)$ \\
\hline 5. $\quad \begin{array}{l}\text { One tablet of IFA given for 100 days } \\
\text { after } 1^{\text {st }} \text { trimester }\end{array}$ & $23(88.5 \%)$ \\
\hline 6. & Two doses of TT vaccine given \\
\hline &
\end{tabular}

*Multiple response

Out of 26 Sahiyyas, only $14(53.8 \%)$ of them were aware about severe anaemia as sign of referral. Amongst those $14,12(85.7 \%)$ responded that severe anaemia could be identified by pallor in tongue and eyes; weakness as a sign of was responded by $10(71.4 \%)$ Sahiyyas and only $2(14.3 \%)$ responded general body swelling as a feature of severe anaemia. As far as management of severe anaemia, only $2(14.3 \%)$ were aware that 200 Iron and folic acid tablets should be advised to mothers having severe anaemia (Table 3).

The study revealed that more than half of Sahiyyas 18 $(69.2 \%)$ had knowledge about vaginal bleeding as danger sign of pregnancy which needs referral. This was followed by knowledge about loss of foetal movements $16(61.5 \%)$; severe anaemia $14(53.8 \%)$ and swollen face/hands $12(46.2 \%)$. Around $35 \%$ of Sahiyyas were aware about severe headache, convulsions and abnormal position of the foetus as sign of referral (Figure 1). 
Table 3: Knowledge of Sahiyya about severe anaemia and management $(n=14) *$.

\begin{tabular}{|lc|}
\hline \multicolumn{1}{|c|}{$\begin{array}{c}\text { Number of } \\
\text { Sahiyyas (\%) }\end{array}$} \\
\hline Knowledge about severe anaemia** \\
\hline Eyes/tongue very pale & $12(85.7 \%)$ \\
\hline Weakness & $10(71.4 \%)$ \\
\hline General body swelling & $2(14.3 \%)$ \\
\hline Management of severe anaemia \\
\hline Referral & $12(85.7 \%)$ \\
\hline Advice 200 IFA tablets & $2(14.3 \%)$ \\
\hline
\end{tabular}

*14 Sahiyyas out of 26 were aware of severe anaemia

***Multiple responses

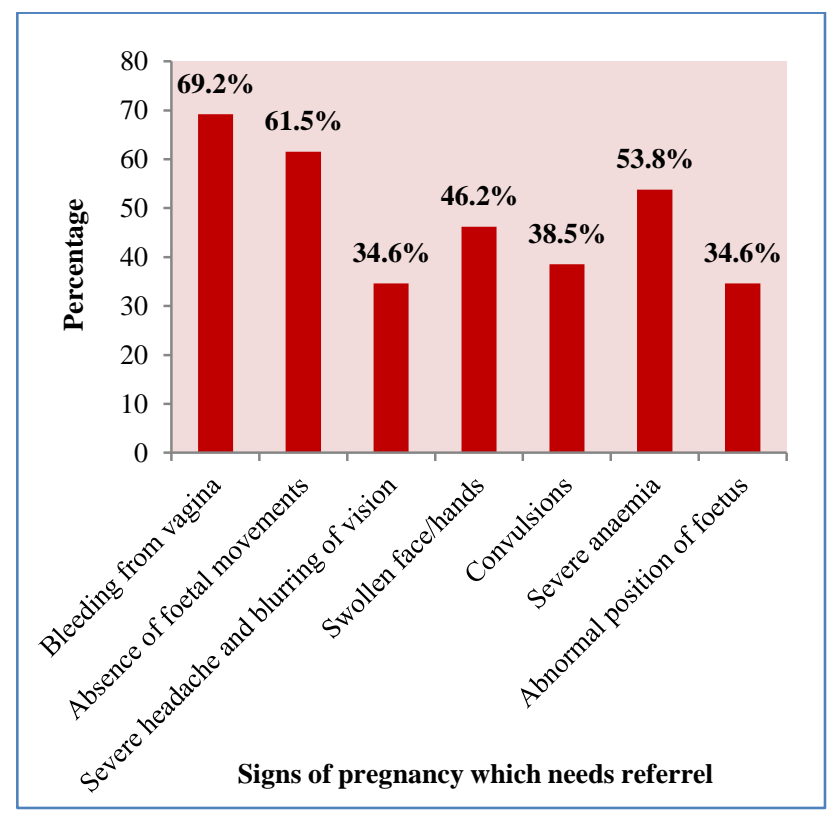

Figure 1: Knowledge of Sahiyyas about signs of pregnancy which needs referral $(n=26)$ (Multiple response).

\section{Responses of beneficiaries regarding help received from Sahiyya}

In the study, out of total 336 beneficiaries, 314 (93.4\%) could recognize Sahiyya of her own village and a very few could not. Out of 336 beneficiaries, 322 (95.8\%) got their pregnancy registered at health centre and rest 14 (4.2\%) did not register (Table 4).

Out of 322 registered beneficiaries, only 226 (70.2\%) received help from Sahiyya while registration which included $87(65.9 \%)$ pregnant women and $139(73.2 \%)$ women having children under 3 years of age (WCU 3 years). Rest 96 (29.8\%) received help from AWW, relatives and friends. As far as job responsibility of Sahiyya in relation to mobilization is concerned, out of total 322 registered beneficiaries only 196 (60.9\%) were mobilized by Sahiyya during ANC checkups (Table 5).
Table 4: Response of beneficiaries regarding registration of pregnancy $(n=n 1+n 2=336) *$.

\begin{tabular}{|c|c|c|c|}
\hline & \multicolumn{2}{|c|}{ No. of beneficiaries } & \multirow{2}{*}{$\begin{array}{l}\text { Total } \\
\text { beneficiaries } \\
(\%) \\
(\mathbf{n}=336)\end{array}$} \\
\hline & $\begin{array}{l}\text { Pregnant } \\
\text { women }(\%) \\
(n 1=140)\end{array}$ & $\begin{array}{l}\text { WCU } 3 \text { years } \\
(\%) \\
(\mathrm{n} 2=196)\end{array}$ & \\
\hline \multicolumn{4}{|c|}{ Can recognize Sahiyya of her village? } \\
\hline Yes & $126(90.0 \%)$ & $188(95.9 \%)$ & $314(93.4 \%)$ \\
\hline No & $14(10.0 \%)$ & $6(3.1 \%)$ & $20(5.95 \%)$ \\
\hline Total & $140(100 \%)$ & $196(100 \%)$ & $336(100 \%)$ \\
\hline \multicolumn{4}{|c|}{ Registration of pregnancy at health centre } \\
\hline Yes & $132(94.3 \%)$ & $190(96.9 \%)$ & $322(95.8 \%)$ \\
\hline No & $8(5.7 \%)$ & $6(3.1 \%)$ & $14(4.2 \%)$ \\
\hline Total & $140(100 \%)$ & $196(100 \%)$ & $336(100 \%)$ \\
\hline
\end{tabular}

*Total 336 beneficiaries $n=n 1+n 2$; Pregnant women $(n 1)=$ 140 and Women having children under 3 years (WCU 3 years) of age $(\mathrm{n} 2)=196$

Table 5: Response of beneficiaries regarding help from Sahiyya during registration of pregnancy $(\mathrm{n}=\mathrm{n} 1+\mathrm{n} 2=322) *$.

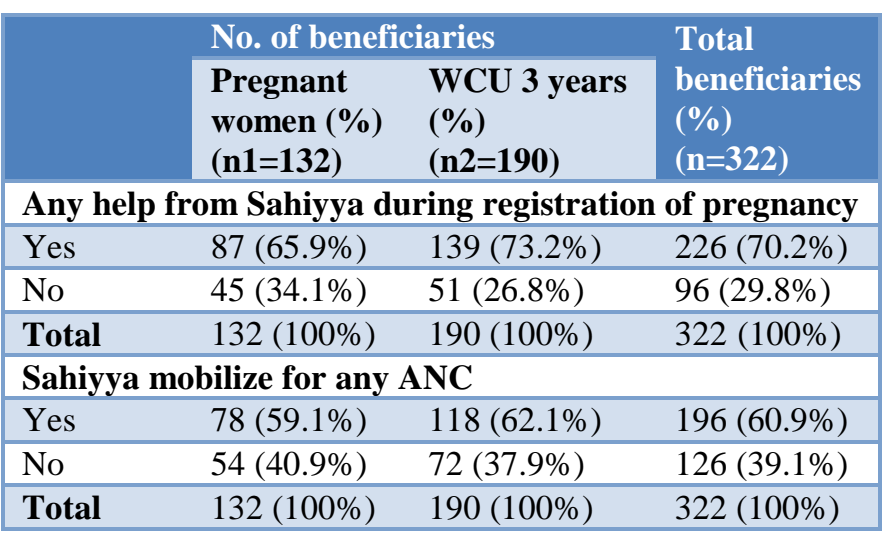

*Only those who had registered their pregnancy were eligible for this question. Pregnant women who had registered their pregnancy $(\mathrm{n} 1)=132$; Women having children under 3 years who had registered their pregnancy $(\mathrm{n} 2)=190$

Out of 196 beneficiaries who were mobilized and counselled by Sahiyya, most of them responded that the ANC components availed by them through help from Sahiyya were weight measurement in total by 178 (90.8\%) beneficiaries, counseling about IFA by 175 $(89.3 \%)$ and TT injection in $162(82.6 \%)$ beneficiaries. Vital components like blood pressure measurement $(58.7 \%)$, blood test $(69.4 \%)$ and urine test were the components not much availed by them $(56.1 \%)$ (Table 6$)$.

In the study out of 336 beneficiaries, 40 of them developed complications during delivery [Pregnant women $=11$; Women having children under 3 years (WCU 3 years $)=29$ ]. Out of 11 pregnant women who developed complications only $6(54.5 \%)$ were accompanied by Sahiyya to health centre. From the second group of beneficiary, out of 29 WCU3yrs who 
developed complications, only 13 (44.8\%) were accompanied by Sahiyya (Table 7).

Only $78(23.2 \%)$ and $63(19.9 \%)$ out of 336 beneficiaries responded that they had received advices on nutrition and adequate rest during pregnancy from Sahiyya during their home visits (Table 8).

Table 6: Response of beneficiaries regarding help by Sahiyya to avail ANC components $(n=n 1+n 2=196) *$.

\begin{tabular}{|llll|}
\hline $\begin{array}{l}\text { Help by } \\
\text { Sahiyya in } \\
\text { availing } \\
\text { components } \\
\text { of ANC by } \\
\text { women }\end{array}$ & $\begin{array}{l}\text { No. of beneficiaries } \\
\text { women }(\%) \\
(\mathbf{n 1 = 7 8})\end{array}$ & $\begin{array}{l}\text { WCU 3 } \\
\text { years }(\%) \\
(\mathbf{n} 2=118)\end{array}$ & $\begin{array}{l}\text { Total } \\
\text { beneficiaries } \\
(\%) \\
(\mathbf{n}=196)\end{array}$ \\
\hline $\begin{array}{l}\text { Weight } \\
\text { measurement }\end{array}$ & $76(97.4 \%)$ & $102(86.4 \%)$ & $178(90.8 \%)$ \\
\hline $\begin{array}{l}\text { BP } \\
\text { measurement }\end{array}$ & $46(58.9 \%)$ & $69(58.5 \%)$ & $115(58.7 \%)$ \\
\hline $\begin{array}{l}\text { Blood } \\
\text { examination }\end{array}$ & $58(74.3 \%)$ & $78(66.9 \%)$ & $136(69.4 \%)$ \\
\hline Urine test & $46(58.9 \%)$ & $64(54.2 \%)$ & $110(56.1 \%)$ \\
\hline $\begin{array}{l}\text { IFA tablets } \\
\text { intake }\end{array}$ & $72(92.3 \%)$ & $103(87.3 \%)$ & $175(89.3 \%)$ \\
\hline TT injection & $65(83.3 \%)$ & $97(82.2 \%)$ & $162(82.6 \%)$ \\
\hline
\end{tabular}

*Only those who had received help by Sahiyya during antenatal checkups were eligible for this question. Pregnant women who had received help from Sahiyya during ANC checkups (n1) = 78 , Women having children under 3 years who received help from Sahiyya during ANC checkups (n2) $=118$

**Multiple response

Table 7: Response of beneficiaries regarding help by Sahiyya during complication of pregnancy $(\mathrm{n}=\mathrm{n} 1+\mathrm{n} 2=40) *$

\begin{tabular}{|llll|}
\hline $\begin{array}{l}\text { Does Sahiyya } \\
\text { accompany } \\
\text { to health } \\
\text { centre during } \\
\text { complications } \\
\text { of pregnancy }\end{array}$ & $\begin{array}{l}\text { No. of beneficiaries } \\
\text { Pregnant } \\
\text { women }(\mathbf{\%})\end{array}$ & $\begin{array}{l}\text { WCU 3 years } \\
(\mathbf{\%})\end{array}$ & $\begin{array}{l}\text { Total } \\
\text { beneficiaries } \\
(\mathbf{n} 2=\mathbf{2 9})\end{array}$ \\
\hline Yes & $6(54.5 \%)$ & $13(44.8 \%)$ & $19(47.5 \%)$ \\
\hline No & $5(45.4 \%)$ & $16(55.2 \%)$ & $21(52.5 \%)$ \\
\hline Total & $11 * *(100 \%)$ & $29 * * *(100 \%)$ & $40(100 \%)$ \\
\hline
\end{tabular}

*Pregnant women who developed complication during pregnancy $(\mathrm{n} 1)=11$; Women having children under 3 years who developed complication $(\mathrm{n} 2)=29$,

**Complications developed in pregnant women - Malaria (2), Vaginal bleeding (2), Fever (2), Swelling of legs and body (3), Loss of foetal movements (2)

****Complications developed in WCU 3 years - Malaria (9), Swelling of body and legs (5), Bleeding per vagina (2), Bad obstetric history (5), pain abdomen (4), Decreased foetal movement (4)
Table 8: Response of beneficiaries regarding advices received from Sahiyya during home visits $(\mathrm{n}=\mathrm{n} 1+\mathrm{n} 2=336) *$

\begin{tabular}{|c|c|c|c|}
\hline \multirow{2}{*}{$\begin{array}{l}\text { Advices } \\
\text { received } \\
\text { from Sahiyya } \\
\text { during home } \\
\text { visits*** }\end{array}$} & \multicolumn{2}{|c|}{ No. of beneficiaries } & \multirow[b]{2}{*}{$\begin{array}{l}\text { Total } \\
\text { beneficiaries } \\
(\%) \\
(\mathbf{n}=336)\end{array}$} \\
\hline & $\begin{array}{l}\text { Pregnant } \\
\text { women } \\
(\%) \\
(n 1=140)\end{array}$ & $\begin{array}{l}\text { WCU } 3 \\
\text { years }(\%) \\
(n 2=196)\end{array}$ & \\
\hline $\begin{array}{l}\text { Nutrition } \\
\text { advice }\end{array}$ & $31(22.1 \%)$ & $47(24.0 \%)$ & $78(23.2 \%)$ \\
\hline Advice on rest & $30(21.4 \%)$ & $37(18.9 \%)$ & $67(19.9 \%)$ \\
\hline $\begin{array}{l}\text { Birth plan for } \\
\text { safe delivery }\end{array}$ & $95(67.8 \%)$ & $98(50 \%)$ & $193(57.4 \%)$ \\
\hline
\end{tabular}

*Total 336 beneficiaries $=$ Includes Pregnant women $(\mathrm{n} 1=140)$ and women having children under 3 years of age $(\mathrm{n} 2=196)$, **Multiple response

\section{Responses of AWWs and ANMs about services delivered by Sahiyyas:}

Regarding frequency of contacts of Sahiyya with AWW, $11(68.7 \%)$ out of 16 AWW and $3(50 \%)$ out of 6 ANM responded that Sahiyya meets them more than 5 times a month and the rest responded that frequency of contacts of Sahiyya with them is less than five times a month. Out of 16 AWWs, $12(75 \%)$ of them were fully satisfied with the services of Sahiyya; $2(12.5 \%)$ were somewhat satisfied and rest $2(12.5 \%)$ were not satisfied. Out of 6 ANM, $4(66.7 \%)$ were fully satisfied and rest $2(33.3 \%)$ were somewhat satisfied with their services (Table 9).

Table 9: Response of AWW and ANM regarding frequency of contacts and work satisfaction of Sahiyyas.

\begin{tabular}{|c|c|c|}
\hline & $\begin{array}{l}\text { Response of } \\
\text { AWW }(\%) \\
(n=16)\end{array}$ & $\begin{array}{l}\text { Response of } \\
\text { ANM }(\%) \\
(\mathbf{n}=6)\end{array}$ \\
\hline \multicolumn{3}{|c|}{ Frequency of contact of Sahiyya with health workers } \\
\hline $\begin{array}{l}\text { More than } 5 \text { times in a } \\
\text { month }\end{array}$ & $11(68.7 \%)$ & $03(50 \%)$ \\
\hline 2 to 5 times in a month & $03(18.7 \%)$ & $03(50 \%)$ \\
\hline $\begin{array}{l}\text { Less than } 2 \text { times in a } \\
\text { month }\end{array}$ & $02(12.5 \%)$ & 0 \\
\hline Total & $16(100 \%)$ & $6(100 \%)$ \\
\hline \multicolumn{3}{|c|}{ Satisfied with the services of Sahiyya } \\
\hline Fully satisfied & $12(75 \%)$ & $04(66.7 \%)$ \\
\hline Somewhat satisfied & $02(12.5 \%)$ & $02(33.3 \%)$ \\
\hline Not satisfied & $02(12.5 \%)$ & 0 \\
\hline Total & $16(100 \%)$ & $6(100 \%)$ \\
\hline
\end{tabular}

\section{DISCUSSION}

The ASHAs represent the cornerstone of NRHM's strategy to address the Millennium Development Goals (MDGs) on health related indicators. ${ }^{11}$ The Sahiyya programme had completed its seven years and now she is 
a well-known entity in villages of Jharkhand. She is trained in basic health needs of the community including MCH component and performing her assigned job. A Rapid Appraisal of Sahiyya in Jharkhand, under Rapid Assessment of Health Interventions (RAHI ProjectPhase I) was conducted in the year 2007-2008 with support from United Nations Population Fund (UNFPA) to assess the acceptability of Sahiyya and their functioning. ${ }^{6}$ After the RAHI project in Jharkhand, the present study has tried to find out the present scenario after seven years of her existence in Jharkhand.

\section{Socio-demographic profile of Sahiyyas}

The NRHM guidelines put an emphasis that ASHAs should preferably of 25-45 years of age and educated atleast up to eighth standard. In the present study, it was found that nearly half $42.31 \%$ of Sahiyyas belonged to the age group 32-37 years of age. The age structure of Sahiyyas can be considered to be young as more than $70 \%$ of Sahiyyas are below 35 years of age and none above 45 years. Similar observations were seen by Swain $\mathrm{S}$ et al. ${ }^{12}$ (2008) in Orissa and Kumar S et al. ${ }^{13}$ (2012) in Uttar Pradesh. In the present study out of 26 Sahiyyas, most of them $21(80.8 \%)$ had formal education of $8^{\text {th }}$ standard and above; $4(15.4 \%)$ had studied below $8^{\text {th }}$ standard and one was illiterate. The literacy rate in rural Jharkhand is $67.81 \%{ }^{14}$ which is one of the reasons for education relaxation for Sahiyya selection. This is reflected in the study where around $20 \%$ of Sahiyyas in the field practice area were educated below eighth standard. Illiterate ASHAs were also found in study conducted by Saxena V et al. ${ }^{15}$ (2012) and by Haider S et al. $^{6}$ (2008) in Jharkhand.

In the present study $65.4 \%$ Sahiyyas belonged to SES class IV (Upper lower class) and $34.6 \%$ belonged to socio-economic status class V (lower). Monetary problems could be one of the reasons which have curtailed them to move forward. These findings were in contrast to a study conducted by Saxena $\mathrm{V}$ et al. ${ }^{15}$ were nearly half of ASHAs belonged to Class II (upper middle class) followed by class III (lower middle class) and class I (upper class).

In a study conducted under RAHI (Rapid Assessment of Health and Intervention) phase-I project by Haider $\mathrm{S}$ et al. $^{6}$ (2008) in Jharkhand, Sahiyyas were assessed to understand their acceptability among the beneficiaries. The study revealed that, only $24.2 \%$ had heard about Sahiyya and $22.2 \%$ could recognize Sahiyya of her tola (hamlet). The findings of the present study revealed that ability of women to recognize Sahiyyas has increased from $22.2 \%$ since 2008 to $93.4 \%$. This shows that Sahiyya has become a well-known entity in community.

\section{Maternal health}

Knowledge of Sahiyyas: Under antenatal care job assigned to Sahiyyas are counselling pregnant women for early registration of her pregnancy, accompany them for antenatal checkups, make home visits and counsel pregnant women regarding adequate rest and nutritious diet during pregnancy. All 26 Sahiyyas in the field practice area were aware about helping beneficiaries in registration of pregnancy and mobilization during antenatal checkups as one of their job responsibilities. This finding of our study was better than similar study conducted by Swain $\mathrm{S}$ et al. ${ }^{12}$ were knowledge regarding registration of pregnancy was found in $68.8 \%$ ASHAs. The reason could be that in last six years the knowledge and experience of Sahiyyas might have increased and they are well versed now with their job responsibility regarding registration. The findings of our study regarding knowledge of ASHAs about accompanying pregnant women to the hospital for antenatal checkups were almost similar to study conducted by Swain $\mathrm{S}$ et al. $^{12}$ in Orissa, $2008(92.5 \%)$ and Kumar $\mathrm{S}$ et al. ${ }^{13}$ in Eastern Uttar Pradesh $(97.8 \%)$ and slight better than study conducted on ASHAs in Udaipur, Rajasthan (2009) by Bhatnagar $\mathrm{R}$ et al. ${ }^{16}$ (76.7\%).

The present study revealed that Sahiyya's knowledge regarding signs of referral were slight better than study conducted by Gark PK et al. ${ }^{17}$ (2013) in Haryana where $20.95 \%$ ASHAs were aware about vaginal bleeding; $25.7 \%$ about anaemia and $17.14 \%$ regarding absence of foetal movements as danger signs of pregnancy. Findings similar to present study were reported by Uttekar BP et al. ${ }^{18}$ in Rajasthan (2007) where majority of ASHAs were only aware about excessive bleeding (67.1\%) and anaemia $(30.1 \%)$ as danger signs with less number of ASHAs being aware of other important danger signs of pregnancy.

Responses of beneficiaries: The present study revealed that only $23.2 \%$ and $19.9 \%$ beneficiaries responded that they had received advices on nutrition and adequate rest during pregnancy from Sahiyya during their home visits. Counselling regarding nutrition, rest and other health related issues was drawing lesser attention by Sahiyyas and were not done passionately by her, the reason being they are not incentivized. The findings of the study were similar to a study conducted by Saxena V et al. ${ }^{15}$ were only $22 \%$ ASHAs provided health education and study conducted by Haider S et al. ${ }^{6}$ and Srivastava DK et al. ${ }^{19}$ (2009) in Uttar Pradesh, were only $16.1 \%$ and $21.6 \%$ ASHAs provided health and nutrition education during pregnancy.

\section{CONCLUSIONS}

Perception of Sahiyyas about the antenatal components reflected that awareness about blood pressure measurement, blood test and urine test were the parameters about which they were not much aware of and still there is a lacunae in their knowledge. Knowledge of Sahiyyas as well as her skills needs to be strengthened in the field of maternal health services. Assessment of Sahiyyas when summarized on the basis of responses of 
beneficiaries, AWWs and ANMs indicated that though Sahiyyas were well aware of her responsibilities related to counselling mothers on diet, rest and other health advices through home visits, but these were not being done passionately by her as other incentive oriented jobs. Thus trainings should be conducted timely with periodic refresher trainings imparted to sensitize Sahiyyas about their roles and responsibilities on maternal care. The trainings should also focus upon motivating her to conduct home visits regularly.

\section{ACKNOWLEDGEMENTS}

We would like to thank all the beneficiaries, AWWs, ANMs and Sahiyyas who were the backbone of this study and had willingly participated in the study.

\section{Funding: No funding sources}

Conflict of interest: None declared

Ethical approval: The study was approved by the institutional ethics committee of RIMS, Ranchi, Jharkhand

\section{REFERENCES}

1. NRHM. National rural health mission (2005-2012). In: NRHM, eds. Mission Document. New Delhi: Ministry of Health and Family Welfare, Government of India; 2005.

2. NRHM. Reading material for ASHA. In: NRHM, eds. Book No-1, National Rural Health Mission. New Delhi: Ministry of Health and Family Welfare, Government of India; 2012.

3. NRHM. Guidelines for community process. In: NRHM, eds. ASHA Guidelines Part A. New Delhi: National Rural Health Mission, Ministry of Health and Family Welfare; 2013.

4. National Rural Health Mission. ASHA data, 2014. Ministry of Health and Family Welfare, Government of India. Available at: http://www.nrhm.gov.in/communitisation/asha/asha -data.html. Accessed May 2014.

5. National Rural Health Mission. Update on the ASHA programme. In: NRHM, eds. NRHM Update. New Delhi: The National Health System Resource Centre; July 2013.

6. Haider S, Adhish V, Gupta S, Dhar N, Datta U, Menon $S$, et al. A rapid appraisal of Sahiyya (ASHA) in Jharkhand. Health Popul Perspect Issues. 2008;31(2):80-4.

7. Policy Reform Options Database (PROD), India. Sahiyya movement, Jharkhand, 2014. Available at: http://hsprodindia.nic.in/listdetails.asp?roid=176. Accessed June 2014.

8. National Rural Health Mission (NRHM). Influence on antenatal care services by ASHA's intervention in Jharkhand. In: NRHM, eds. A Study through
RAP. Kolkata: Tagore Society For Rural Development (TSRD); 2014.

9. Government of India (GOI). Special bulletin on maternal mortality in India, 2010-12. In: GOI, eds. GOI Bulletin. India: Office of the Registrar General; 2013.

10. Government of India (GOI). SRS bulletin. In: GOI, eds. GOI Bulletin. India: Registrar General of India; September 2013.

11. Nirupam Bajpai, Ravindra H. Dholakia. Improving the performance of accredited social health activists in India. In: Nirupam Bajpai, Ravindra H. Dholakia, eds. Working Papers Series. Columbia: Columbia Global Centers; May 2011.

12. Swain S, Swain P, Nair KS, Dhar N, Gupta S, Nandan D. A rapid appraisal of functioning of ASHA under NRHM in Orissa. Health Popul Perspect Issues. 2008;31(2):73-9.

13. Kumar S, Kaushik A, Kansal S. Factors influencing the work performance of ASHA under NRHM: a cross sectional study from eastern Uttar Pradesh. Indian J Community Health (IJCH). 2012;24(4):325-31.

14. Office of the Director of Census Operations, Ranchi, Jharkhand. RIADA, Central office building, 2nd floor, Namkum, Ranchi. Available at: www.censusindia.gov.in.

15. Saxena V, Kakkar R, Semwal VD. A study on ASHA- a change agent of the society. Indian J Community Health (IJCH). 2012;24(1):15-8.

16. Bhatnagar R, Singh K, Bir T, Datta U, Raj S, Nandan D. An assessment of performance based incentive system for ASHA Sahyogini in Udaipur, Rajasthan. Indian J Public Health. 2009;53(3):16670.

17. Garg PK, Bhardwaj A, Singh A, Ahluwalia SK. An evaluation of ASHA worker's awareness and practice of their responsibilities in rural Haryana. Natl J Community Med. 2013;4(1):76-80.

18. Uttekar BP, Barge S, Khan W, Deshpande Y, Uttekar V, Sharma J, et al. Assessment of ASHA and Janani Suraksha Yojana in Rajasthan. In: Uttekar BP, Barge S, Khan W, Deshpande Y, Uttekar V, Sharma J, et al., eds. Sponsored by UNFPA. New Delhi: Centre for Operations, Research \& Training, Vadodara; April 2007.

19. Srivastava DK, Prakash S, Adhish V, Nair KS, Gupta S, Nandan D. A study of interface of ASHA with the community and the service providers in Eastern Uttar Pradesh. Indian J Public Health. 2009;53(3):133-6.

DOI: 10.5455/2394-6040.ijcmph20150513

Cite this article as: Karir S, Haider S, Kashyap V, Sagar V, Singh SB. Assessment of Sahiyya (Accredited Social Health Activist) in relation to antenatal services: Ormanjhi, Ranchi, Jharkhand. Int J Community Med Public Health 2015;2:130-6. 